\title{
Post-extractivism: From Discourse to Practice-Reflections for Action
}

\author{
Alberto Acosta
}

\begin{abstract}
The predominant school of thought leads us to believe that an economy without growth is an impossibility and that the only means of achieving development is through economic growth. In turn, this growth requires ever-larger amounts of natural resources to sustain increasing global demand, while generating revenue for the global South to overcome its 'underdevelopment'. Reality nevertheless tells us that moving beyond this vision is the most pressing challenge of our time: to overcome 'the religion of economic growth' and make room for new approaches that will enable us to escape the extractivism 'trap'. This chapter proposes to move towards a non-capitalist society inspired by the visions, values, experiences and practices of the different forms of buen vivir that can be found among diverse indigenous populations across our planet.
\end{abstract}

We must recover, maintain and transmit the historical memory because what begins as forgetting ends up as indifference.

JOSE SARAMAGO

\section{$1 \quad$ Introduction}

The dominant school of thought leads us to believe that there is no economy without growth. To achieve progress, we are conditioned to believe that

* This chapter is a compilation of reflections that have been proposed and published elsewhere on an ongoing basis. The development of any alternative requires continuous re-examination and should be the object of broad and sustained debate.

(C) ALBERTO ACOSTA, 2017 | DOI 10.1163/9789004351677_006

This is an open access chapter distributed under the terms of the CC-BY-NC License. 
the only avenue is economic growth. And to ensure this growth, there must be increasingly large volumes of natural resources to sustain ever-growing global demand. At the same time, this effort, increasingly leveraged by extractivism, can ensure revenues for the global South - which generally supplies these resources-so that it might overcome its 'underdevelopment'. The reality, however, tells us that moving beyond these visions is now our greatest challenge.

The limits of nature, overwhelmed by the expansion imposed by capitalistic modernity and its process of accumulation, are increasingly evident and their transgression unsustainable. Simultaneously (inherent to capitalism and a civilisation based on inequality), there are multiple and growing ruptures that lead to complex and painful processes: for example, growing levels of migration from countries in the South to the USA and the European Union. Unhinged extractivism generates extreme violence such as that caused by the interventions of Western powers in Iraq or Syria, their real objective being to control oil deposits. And this violence feeds the migratory flow by increasing the number of refugees affected by war. To complicate this perverse scenario even further, we know, to the point of saturation, that economic growth does not necessary imply happiness, even in 'developed' countries. Additionally, this growth almost always increases gaps in societies: the riches of a few are often sustained by the exploitation of the many and of nature. Without a doubt, it is important to initiate a discussion that recognises that the capitalist system - according to the contentions of the Ecuadorian philosopher Bolivar Echeverria (2010) - lives to suffocate life and drain the living world, by which he refers to both labour and nature.

From this perspective, it becomes indispensable to stop the maelstrom of economic growth and even 'de-grow', particularly in the global North. In a finite world, there is no place for permanent economic growth given that it could lead to an increasingly unsustainable situation in environmental terms, and create a more explosive situation in social terms. This challenge, as we will see later in this chapter, should go hand in hand with post-extractivism.

The interconnections underpinning this process in a global context are easy to foresee: for example, if economies in the North stop growing or shrink, the demand for raw materials will diminish; in this scenario, the countries of the South would be ill-advised to continue sustaining their economies with exports of raw materials. Furthermore, economic growth is hardly synonymous with 'development'; it is akin to chasing a ghost. 
It is thus indispensable for poor countries to responsibly address the subject of growth and rethink 'development'. Freeing ourselves from the shackles of 'development' could strengthen our capacities to find other avenues that allow us to build societies and guarantee a dignified life for all citizens, based on the visions and proposals of each society, and not on an unviable copy and caricature of other realities.

This requires putting-from the outset-economic growth in its place and, at the very least, differentiating 'good' growth from 'bad' growth. Manfred Max-Neef, the Chilean economist (and Alternative Nobel Prize winner), is categorical in this respect: 'If I dedicate my time, for example, to totally plundering a natural resource, my economy will grow but at the cost of ending up poorer. In reality, people do not perceive the abhorrent nature of the conventional macroeconomy, which calculates the loss of patrimony as an increase in income. Behind every figure of growth, there is a human story and a natural story. If these stories are positive, growth is welcome; in any case, growing little but well is preferable to growing a lot but poorly'. (Our transl.) This line of questioning does not in any way imply sustaining current inequalities and social inequalities that permit the opulent groups in the North and South to maintain their privileged ways of life.

It has been proven that economic growth, provoked by the voracity of capital (which accumulates by producing and speculating), leads to an increase in inequalities. Social inequality is a global issue that also affects 'successful' economies, which are posting increasingly higher levels of frustration and unhappiness. We need only look at some figures on the unequal distribution of wealth across the globe, which is also seen in 'developed' countries, ${ }^{2}$ to see that this scenario has worsened over the past few years: while in 2010, 388 people had accumulated the same amount of wealth as more than half of the global population (ca. 3.500 million people), by 2015 this number had fallen to 62 people according to an Oxfam (2016) report. According to this same source, the riches in the hands of these 62 richest people had increased by 44 per cent; in only five years, the wealth in the hands of the poorest half of the population fell by more than a billion dollars, plummeting by 41 per cent.

As such, to begin any post-extractivist and post-growth option, it is important to focus on building societies that are anchored in equality and equities (in the plural) that allow us to create an ecological and social balance.

1 See the open letter of Max-Neef to the Chilean Minister of Economy, December 4, 2001.

2 As an example, we can review the figures for inequity in Germany, the country of the 'inventors' of the highly promoted concept of the social market economy, and where the results are rather sobering: in 2008, the richest 10 per cent of the population held 53 per cent of the assets while one half of the population owned one per cent of the assets (Amann et al., 2014). 
It is important to find a way to exit the current capitalistic civilisation but we must remember that this will not happen overnight. We have to be open to transitions that entail thousands of diverse alternative practices-many of which are not capitalist - across the planet; practices that are oriented towards utopic horizons that propose a life among human beings and between human beings and nature. This entails patiently and confidently building and rebuilding, which also entails dismantling various fetishes of capitalist society. An excellent example of global action ${ }^{3}$ was - and continues to be-the proposal to leave crude oil in the subsoil of the Ecuadorian Amazon: the initiative YasuniITT. This proposal contends that the richest countries, which are largely responsible for grave environmental problems, must assume their responsibility to stop and reverse these imbalances. This initiative has not succeeded because rich countries have failed to assume their responsibilities and the Ecuadorian government has been incapable of handling the revolutionary challenge posed by civil society. This is a key point. Alternative values, experiences and civilisation practices are available, and include those offered by buen vivir (or sumak kawsay in indigeneous language) from indigenous communities of the Andes and the Amazon. Better yet, we can speak of 'good coexistences', in the plural, to avoid implying that there is only one homogenous form of buen vivir that would be impossible to build. These visions require a world in which other 'worlds' can enter without risk of being marginalised or exploited, and which calls for another economy based on the harmony, solidarity and reciprocity proposed by buen vivir.

All of this opens the door to a new type of civilisation in line with the visions and experiences that reflect the praxis of the full, harmonious life that is proposed in different corners of the world. In fact, there are many experiences and contributions from different latitudes that can come together to build alternatives to move away from extractivism.

This is evident given that the challenge entails building strategic transition in various ambits but without establishing universally valid recipes. In this chapter, we will look at just a few of the main ideas of the debate. A pending task will be to look at these ideas within the context of concrete cases, but this is beyond the scope of this chapter. In any case, it is important to keep in mind the need to propose joint solutions given that the challenges, such as the serious challenges derived from changes to the global climate, cannot be

3 Certainly, it is necessary to rescue and strengthen all the proposals that tend towards propagating global change, and to build many more (in this regard, see Acosta and Cajas, 2015). 
resolved by each of the countries in an isolated manner. Coordinated responses that cross the spectrum and are global in reach are required. ${ }^{4}$

\section{From Colonial Extractivism to Neocolonial Extractivism}

Let us start with an understandable definition: extractivism makes reference to activities that remove large volumes of non-processed natural resources (or resources that are limited in quantity), particularly for export, to cover the demand in central countries. Extractivism is not limited to minerals or petroleum. Agricultural, forest, fishing and touristic extractivism exist. As such, and in line with Eduardo Gudynas - who proposes this definition - it is better to speak of extractivisms.

Extractivism is a concept that helps explain plundering, accumulation, concentration and colonial and neocolonial devastation, as well as the evolution of modern capitalism and ideas of 'development' and 'sub-development'. Extractivism began more than 500 years ago; neither extractivism nor colonisation (which is tied to extractivism) ended after European domination of America came to an end. Conquest and colonisation, hand-in-hand with extractivism, continue to be present throughout the region of Latin America, in both neoliberal and 'progressivist' countries.

The structuring of the world-economy, the capitalist system, began with the conquest and colonisation of America, Africa and Asia. The modality of commodity-export (or extractive) accumulation was a foundational element of this system, and has been defined by demands that are generated in capitalist centres. Some regions specialised in extracting and producing raw materials and primary goods while others became manufacturing areas, which frequently used the natural resources of impoverished nations. In summary, the majority of 'developed' countries are net importers of nature and the 'underdeveloped' are net exporters of nature. This has led to the entrenchment of primaryexport accumulation, and of extractivism, which is one of its manifestations.

As such, and despite the current emancipating discourse some progressivist governments on the subcontinent have articulated, the region continues to be a strategic territory for global capitalism. This is evident in the fact that

4 The proposals formulated by Gerardo Honty and Eduardo Gudynas (2014) in the framework of the meetings of civil society during the conference for signatories of the United Nations Framework Convenion on Climate Change in Lima (COP20) in December 2014 constitute, in conjunction with other contributions along these lines, a very rich starting point from which to make the leap from criticism to guiding proposals. 
the potential of these countries to act as suppliers of natural resources to central countries has increased with China and India joining the fray. This also has an impact on area infrastructure, where large investments are being made primarily to reduce the costs and times of the extraction or transportation of raw materials. Take, for example, large hydroelectric dams, whose energy is used mainly to meet the demand of extractivist projects in the mining and oil sectors in particular.

\section{$5 \quad$ The Main Pathologies of Extractivism}

To propose post-extractivist responses, it is necessary to identify the problems that must be resolved and determine the capacities available to address them. We are aware of the pathologies that affect economies where authorities and the dominant elite bet primarily on extractivism. Here we would like to mention as critical points several pathologies that generate this scheme of accumulation, which is fed by increasingly pernicious vicious circles:

- Is it normal that these economies experience various 'diseases', particularly the 'Dutch Disease'?5 An abrupt and massive flow of currencies causes an overvaluation of the exchange rate and competitiveness is lost, which has an adverse effect on the manufacturing and agricultural export sectors. Given that the real exchange rate appreciates, resources migrate from the secondary sector to non-tradable segments and to those where booming primaryexport activity either exists or exerts an influence. This distorts the economy by cutting investment funds that could be destined for the very sectors that produce greater added value, more employment, and improvements in the incorporation of technological advances and productive chains.

- Specialising in primary exports-in the long term- has often been a negative strategy due to the trend towards a downturn in the terms of trade. This process favours imported industrial goods but adversely affects exports of primary goods given that these products have low elasticity-income, can be replaced by synthetics, and do not possess monopoly power given that their technological contributions and innovative development capacities are low (they are commodities, meaning that their prices are set primarily by the

5 Other income exists that can provoke similar effects, including remittances, foreign investment, assistance for development, and even massive inflows of private capital (Schuldt, 1994). 
logic of market competition), and that raw material content is becoming increasingly less significant in the manufacturing process. This impedes countries that specialise in exporting highly homogenous merchandise, meaning raw materials, from fully participating in gains in terms of economic growth and global technical progress.

- The high rate of sustained gains on differential, or Ricardian rents (derived from natural resources and the fruit of human effort) that contain primary goods, leads to their overproduction. Additionally, these rents-more so when no royalties or corresponding taxes are collected-create surplus gains that distort a country's resource allotment. This makes it important to 'nationalise natural resources' (such as oil) to at least drive efforts to better distribute the extraordinary gains and revenues obtained by companies.

- The volatility in the price of raw materials on the global market has led primary-export economies to suffer recurring problems in their balance of payments and fiscal accounts, causing severe dependence on external financing and subjecting national economic and sociopolitical activity to erratic fluctuations. This is exacerbated when prices fall in international markets, consolidating the crisis in the balance of payments. The situation is worsened by major capital flight during boom cycles, alongside tenuous local capital, which heightens external constraints and problems of indebtedness during the boom periods.

- Dependence on foreign markets, although paradoxical, is even more marked in times of crisis, especially in the event of generalised government blockades. Most economies dependent on primary resource exports fall into the trap of forcing up extraction rates when prices drop. They seek to sustain, by any means possible, the revenues generated by primary exports. This can prove beneficial: a larger supply of raw materials-oil, minerals or foodin times of depressed prices creates a surplus, which reduces prices even further, thus generating 'impoverishing growth' (Bhagwati, 1958).

- The boom in primary exports also attracts the watchful international banking sector, which disburses loans abundantly during boom times, as if this were a sustainable approach. This financing is received with open arms by governments and business people who believe in permanent miracles. This provokes overproduction of primary resources still further (through oil subsidies), which increases distortions in the sector. As historical experience shows, the future of the economy is mortgaged early on in a crisis when the inevitable time comes to service the sizeable external debt that was contracted during the period of export euphoria. And the ability to service this debt becomes particularly burdensome as export prices fall and interest rates in metropolitan economies increase. 
- The abundance of external resources, fed by exports of oil or minerals (as has been the case in the last few years) creates a consumption boom, which leads to the aforementioned consequences. In this context, resources are wasted given that national products are substituted by external products, a process that is stoked by the overvaluation of the exchange rate due to the massive capital inflow. More investment and public expenditure, without due provisions, encourage imports and not necessarily domestic production.

- This experience also illustrates and confirms that extractivism does not generate dynamic productive chains. Nor does it ensure integration or synergistically productive links in terms of consumption and fiscal ties. Extractivism also fails - to an even greater degree - to facilitate or guarantee technological transfer and the generation of externalities in favour of other sectors. From this, we can derive one of the classic characteristics of primary-export economies, present since colonial times: enclaves where extraction is generally isolated from the rest of the economy, such as the case of oil, mining or monocrops.

- Closely related is the fact that companies controlling the exploitation of non-renewable natural resources in the form of enclaves, due to the location and form of exploitation, frequently become powerful business entities (or para-states) within relatively weak national states. This weakens the logic of the nation-state and gives way to the 'deterritorialisation' of the state, leaving the responsibility for attending to social needs, for example, to extractivist companies. This leads to disorganised and unplanned management of these regions, which often operate outside national laws. All of this creates an atmosphere of violence and increasingly higher levels of marginality, which leads to repressive, myopic and clumsy responses from certain states that fail to fulfil social and economic obligations.

- In these economies, there is low absorption of the labour force (and the labour force that is absorbed tends to be overexploited). Along the same lines, the unequal distribution of income and assets leads to a dead end on both sides: the marginal sectors, with higher capital productivity than the modern segments, do not accumulate given that they lack resources to save and invest, while the modern sectors, with higher manual labour productivity, do not invest given that they lack internal markets that ensure attractive returns. This in turn adversely affects the availability of technical resources, a qualified work force, infrastructure and currencies, which discourages investment and subsequent activity. This means that these productive apparatuses are defined by structural heterogeneity (Pinto, 1970). 
- In addition to the above mentioned points, there is the argument that, unlike other sectors, extractivist activities (particularly mining and oil) take on limited direct or indirect labour, even if it is well-paid. The sector hires highly qualified managers and specialised workers who are often foreigners. It is a sector that is capital and import intensive and which uses almost exclusively foreign inputs and technology. All of this contributes to the derisory 'internal return' (equivalent to the added value that is maintained in the country) of primary-export activity.

- This generates new social tensions in the regions where these natural resources are extracted given that very few people in these areas are on the payroll of mining or oil companies, nor do they benefit indirectly from the revenues derived from their activities. In terms of monocrops, which require a high concentration of manual labour, labour relations are precarious and include practices of semi-slavery. We need only mention in this regard the banana plantations of Ecuador.

- Derivatives of exports of primary goods consolidate and deepen the concentration and centralisation of income, revenues and political power. Transnational companies are the major beneficiaries in this scenario-seen as promoters of modernity — and are recognised as having 'meritoriously' taken risks to conduct exploration and exploit the natural resources. No one speaks about how this leads to more 'denationalisation' in the economy, partially due to the volume of financing necessary to exploit resources and to the lack of a consolidated national business community, and - to no lesser extent - the lack of government willingness to form strategic alliances with local business people. Additionally, and quite unfortunately, some transnationals have taken advantage of their contribution to the balance of trade to influence power in the country and permanently threaten governments that dare to swim against the tide.

- In these enclave economies, the political structure and dynamic are characterised by 'rentierism' and by the voracity and authoritarianism with which they make decisions. This voracity causes public expenditure to leap way out of bounds and leads to a scenario in which fiscal management lacks adequate planning. This 'voracity effect' consists of a desperate search for and abusive appropriation of a large segment of surpluses in the primary export sector. The politically powerful squeeze the surpluses, sometimes with corrupt mechanisms, to perpetuate power or simply to profit from it.

- Extractivism causes the natural and social environments in which it takes place to deteriorate. This takes place despite some companies' efforts to minimise contamination and to take social action to establish 'friendly' relations with communities. For this reason, there are more and more 
defensive responses from affected communities, which are increasingly repressed by governments and extractivist companies. In this scenario, moves to criminalise social protest become key tools in initiatives to deepen extractivism.

Despite the heavy weight of arguments against primary-export accumulation that gave rise to the theory of the 'resource curse' (Acosta, 2009), it remains undisputed in countries that are predominantly extractivist economies, to such an extent that it seems the real curse is actually their inability to face the challenge of constructing alternatives to the continuation of primary-export accumulation and its undeniable failures.

Once these pathologies have been recognised, we can present concrete recommendations to address them. But this isn't sufficient. There is a fundamental issue at stake. The massive appropriation of extracted natural resources brings with it violence that tramples human rights and the rights of nature; 'this is not the result of one type of extraction but instead is a necessary condition to engage in the appropriation of natural resources', as Eduardo Gudynas (2014) wisely indicates.

In synthesis, there is no good extractivism ${ }^{6}$ or bad extractivism. Extractivism is what it is: a set of activities to massively extract primary resources for export, which, within capitalism, becomes a fundamental element of the modality of primary-export accumulation. In this sense, extractivism is essentially predatory, like capitalism. 'The capitalist way lives to suffocate life and the world of life; this process has been taken to such an extreme that the reproduction of capital can only take place if it destroys human beings to the same extent as nature. The revolution implies transforming and subverting capitalism rather than learning to live within this system' (Echeverria, 2010, our transl.).

All aspects described above with regard to extractivism interrelate with typical elements of 'underdevelopment':

- A weak internal market driven primarily by low income and enormous inequalities in the distribution of wealth.

- The growing poverty of the masses contrasts with the concentration of income and assets in only a few hands.

- The presence of outdated productive systems that characterise the structural heterogeneity of the productive apparatus.

6 Except in the case of the use of the term in Portugese, when referring to sustainable extraction of natural resources of the forest, such as chestnuts or wood, which does not affect the existence of the forest and all of its rich diversity. 
- Scarce productive and sector chains, in particular in terms of the ties between export activities and the rest of the economy.

- The productive concentration of non-elaborated goods to serve the external market despite the ups and downs of international prices in the primary sectors, which are also capital intensive and require limited manual labour.

- The lack of adequate integration among the diverse regions of each country, particularly in terms of infrastructure and productive exchange.

- The tendency for wealthy countries to absorb the savings of the poorest regions, which creates 'circular accumulative causation' (Myrdal, 1957), which in turn generates increasingly higher levels of impoverishment while others reap more and more benefits.

- The absence of a modern system of science and technology, based on the development of comparative dynamic advantages.

- Poor management by the state and significant levels of arbitrary behaviour in the bureaucratic apparatus.

- Consistently low expenditure on social policies, particularly in health and education; investment in these sectors is often poorly implemented.

- Massive inefficiencies in the private sector.

- Widespread corruption at the societal level, in both the public and private sectors.

Despite the fact that this reality and its pathologies are well known, after so many decades of dependence on these types of extractivist activities, there are very few effective responses. In the last few years, the most noteworthy response entailed efforts to build stabilisation funds (with some exceptions), whose efficacy depends on the duration of low prices for raw materials in the global market. What is, however, absolutely clear is that dependency on extractivism has increased both in countries with neo-liberal governments and in those that are considered 'progressive'. All of these governments, hand in hand with extractivism, have begun a new developmentalist crusade.

Someone-whether due to bad faith or to ignorance - may be entranced by the following hallucinatory idea: if the primary-export economy generates and perpetuates 'underdevelopment', the solution would consist of halting natural resource exploitation. Obviously, this is a fallacy. In the words of Joseph Stiglitz: 'the natural resource curse is not a matter of fate but a matter of choice' (2006, 198). This should be, at the very least, a democratic choice that establishes the 
bases to drive transition processes that free us from the ties of extractivism without risking life, whatever the reason.

Evidently, there are powerful interests that keep us on this dead-end path and prevent a democratic determination of the economy's course. ${ }^{7}$ There are countries or transnational groups (for example, current Chinese companies) that, taking advantage of the 'naivety' of authorities and the dominant elite, throw out 'lifebelts' by providing some financial resources-many times under conditions that are openly contrary to the interests of the global South-in exchange for keeping the country on the primary-export path.

The goal is to opt for new paths with concrete solutions that are not a mere copy of other situations. To achieve this, we need alliances and consensus that provide answers from the inside out, taking greater advantage of local and national capacities, including those that offer regional integration based on a vision that is inspired by autonomous regionalism and not by the open regionalism proposed by neo-liberals.

Along these lines, the potential of another form of integration comes to the forefront: autonomous integration, which is not just a platform for insertion into the global value chains of transnational capital. And in the meantime, there is a need to propose another civilising horizon, given that, as we know too well—and based on the thought of Ana Esther Ceceña $(2008,11)$ — 'within capitalism there is no solution for life; outside of capitalism there is uncertainty but everything is a possibility. Nothing can be worse than the certainty of extinction. It is the moment to invent, the moment to be free, the moment to vivir bien' (our transl.).

It is important to understand that we cannot overcome extractivism overnight. It is certain that while dragging the chains of capitalism, we must overcome capitalism, for example by strategically using revenues from raw material exports. Here, we propose some basic ideas that are still based, to a large extent, on conventional economics, which is the point from which we will need to build post-extractivist transitions as a basis for a new economy that we can define as the economy of buen vivir.

7 This 'new corporate class' has captured not only the state-doing so, moreover, with little heavy-hitting opposition-but also important communication outlets, pollsters, business consultants, universities, foundations and law firms. In this way, it has become a 'privileged political actor', given that its members possess 'levels of access and influence that no other interest group, strata or social class can match', which, once again, allows them to 'push for the reconfiguration of the rest of the social pyramid'. This 'is about an invisible hand in the State that offers favours and privileges and that later, once obtained, tries to maintain them at any cost', interpreting them as 'acquired rights' (Durand, 2006, our transl.). 
To achieve this, we need to roll out transition strategies while extractionbut on an increasingly less significant scale - of natural resources that are in some way carriers of the 'abundance curse' continues. On this journey, the latent risks of depending on extractivism will remain and maintain the colonial characteristic of raw material exporters. The success of the effort to exit this reality will depend on the coherence of the alternative strategy and, moreover, on the social backing in place. This consideration, nevertheless, cannot be interpreted as a call to 'exit extractivism with more extractivism'.

The task is not simply a matter of extracting more natural resources to obtain revenues to overcome extractivism, nor of optimising extraction by repairing and restoring the environmental and social damage caused by these activities. It is increasingly important to actively include environmental demands, for example a moratorium on oil activity in areas with high biodiversity in the Amazon, which would be in the interests of society in the mid and long term. And even more importantly, we need to transition from an anthropocentric civilisation to a biocentric civilisation; in this regard 'perhaps there is no greater cause since the Universal Declaration of Human Rights than fighting for the Rights of Nature', as the Argentinean senator Fernando Pino Solanas posited in his intervention in the Ethical Tribunal for Natural Rights, in Paris in December 2015.

The first step is very concrete: it is necessary to obtain the maximum social benefit possible from each ton of mineral or each barrel of oil extracted instead of maximising extraction. Along these lines, it will be necessary to revise various contracts that have been proven to adversely affect national interests.

Keeping in mind each of the general proposals that have been outlined above, and without professing to have addressed all of the points that must be considered, in the text below we propose some relevant aspects that seek to fuel the debate on a democratic construction of responses that transform the existence of important natural resources into a lever for well-being in order to overcome the 'abundance curse' that replicates, time and time again, 'underdevelopment'.

\subsection{Elements for a Productive Transformation}

Among the requirements for achieving post-extractivism, we find the need to overcome low productivity in the productive segments for goods that serve the needs of the majority of the population and that account for the majority of

8 There are various proposals in this regard; see the ideas proposed by Schuldt (1994) and Schuldt and Acosta (2000). 
manual labour jobs. To achieve this, we need to make massive investments, but financing cannot come from the investments themselves given that they do not generate surpluses (nor do they take advantage of differential or Ricardian rents). This obliges us to transfer surpluses to productive segments, particularly those that exploit natural resources (fundamentally for the external market, for example oil or minerals) and also the modern urban segments (which produce luxury goods).

Since traditional segments do not generate substantial gains, producers of primary goods (primarily exporters of natural resources) must fulfil a central role: providing resources - particularly currencies - to ensure that the system will be reproduced and transfer part of the surpluses to traditional segments with elevated capital productivity, which are more intensive in term of imports and employment, they are in charge of satisfying the demand for food and services in the internal market, and in the majority of cases they are less predatory in terms of the environment.

The system of accumulation, in terms of the state's management activities, economic policy and legal-administrative as well as structural-institutional reforms, should concentrate on specific segments during the 'transition phase', with special emphasis on those that produce mass goods (traditional urban and rural segments and, to a lesser extent, some branches of the modern urban segment). Exports with higher internal rates of return, which imply lower socio-environmental impact, must be promoted. And gradually, we will free ourselves of dependence on extractivism.

This inter-segmental transfer should take place in the sociopolitical and cultural organisation of population groups to ensure that they become social subjects. This will allow these groups to develop their own productive forces and become dynamic players in the sociopolitical process. The dispute over a new modality of accumulation is not the only thing at stake; power itself and the move to build a new society, with different consumption patterns and other expectations, are also on the table.

It is important to note, among many other actions that are not mentioned here due to lack of space, that measures that transform and drive agriculture, including food sovereignty, modifying consumption patterns and using productive capacities should be adopted. All of this requires redistributing income and riches. This means transforming the structure for land and water holding and facilitating access to credit and markets (a real and deep agricultural reform).

It is also important to develop a large, qualified labour force to ensure that people lead a dignified life and not simply to favour the accumulation 
of capital. This requires an integral and committed education reform whose conceptualisation is tied to human rights and the rights of nature.

\subsection{New Social and Political Demands}

Different and differentiating economic management also requires social changes that do not depend solely on offering economic rationality for social policies. Its reformulation and orientation must be based on principles of efficiency and solidarity that strengthen the cultural identities of local populations by promoting interaction and integration between popular movements and the economic and social inclusion of the differentiated masses, which will go from playing a passive role in the use of collective goods and services to being autonomous drivers of health, education and transportation initiatives at the local-territorial level.

In political terms, this process would contribute to establishing and strengthening institutions in local and municipal spaces that are representative of the majority by expanding through concentric circles until the national level is covered, and confronting the domination of financial capital and state bureaucracies, which are the most resistant to change.

It will also be necessary to ensure the efficient use of revenues from natural resource extraction and export. This will require fiscal discipline and tax measures that facilitate state expenditure and investment, with sustainable criteria, in a framework of structural policies with long-term horizons. More democracy is required for the design of these norms and policies, given that they would provide the overarching framework for the adequate use of non-renewable resources. We also need to reflect on how to create a savings and stabilisation fund that transforms temporary revenues into longer-term revenues-which will eliminate, or at least reduce, the effect of price volatility — but without using these funds for perverse ends, such as to guarantee the payment of external debts.

This implies managing, at the local and community levels, spaces of real power-real counter-powers of democratic action in the political, economic and cultural realms. From these points, we can develop the embryos of new state institutions, a renewed logic for the market, and a new social coexistence. These counter-powers will be sustained by a collective strategy to build a new image of coexistence: buen vivir or sumak kawsay, which cannot be an abstract vision that casts aside the actors and relations that are present, but rather one that focuses instead on a concrete vision that recognises the actors and their relations as they are now and not as we would like them to be tomorrow. 
The transformation of the productive apparatus must stimulate internal savings (given the growing limitations of the external market and foreign financial flows with regard to feeding productive activities), balanced investment and the development of productive forces.

External capital will not be (nor has it been) a determining factor; extractivist investments even less so. Efforts to generate domestic savings, to promote the suitable use of resources and available capacities, and to develop institutions that are aligned with the objectives that are proposed are far more important.

A fundamental role falls to internal markets, which must strengthen in order to engage internationally in such a way that patterns of domestic consumption are modified and the export basket is diversified thereby adding value. For this reason, policies should align the demand for supplies of final and intermediate goods and their means of production. And these supplies must be based on using internal resources and technologies that are adequate in social and ecological terms.

This transformation does not imply translating the axis of action from the outside-imports and exports - to the inside, meaning basing it on local production that will be projected to the global market. This is not enough. Additionally, this effort is not aligned with the civilising change that is needed. Domestic markets should be supplied with local and national production, and also gradually assume new patterns that are inspired by sustainability, solidarity, reciprocity and sufficiency.

\section{Integration of the Export Sector with the Rest of the Economy}

As the domestic market expands, producers and current exporters will have a growing interest in selling within their own country, either final goods or inputs, and industry will be oriented towards satisfying the demand of the vast majority of the population. In addition, the growing purchasing power of the people will create more incentives for local producers to develop products targeted at the domestic market. In the long run-and this could be another central goal of the alternative strategy - the export sector will be fully integrated into the national economy and, once the domestic market has been exploited, alongside its expansion, the export sector will be able to increase its international competitiveness. Moreover, this integration will need to be linked to a 
new form that coexists with nature as an axis of an economic scheme that is in harmony with Madre Tierra (Mother Earth).

By strengthening the internal market and increasing the quality and quantity of products, these goods can be gradually introduced into the global market, in neighbouring countries in particular, and in accordance with a process of autonomous integration that is more symmetrical, sustainable and equitable. What should be clear is that the global market cannot be the main objective of economic policy. This demands developing competitive capacities internally to perform better in the international sphere. And the unavoidable prerequisite to this consists of developing a modern complex of science and technology that is constantly seeking new knowledge, while-of course-respecting ancestral knowledge and wisdom.

By losing its character as an enclave, the export sector will generate-with productive chains, demand and fiscal components that move from the outside to the inside-more income and employment in other economic sectors and segments in order to break the vicious circle.

At this point, it would be good to remember the recommendation of John Maynard Keynes (2003 [1933]): 'I sympathize, therefore, with those who would minimize, rather than with those who would maximize, economic entanglement among nations. Ideas, knowledge, science, hospitality, travel-these are the things which should of their nature be international. But let goods be homespun whenever it is reasonably and conveniently possible, and, above all, let finance be primarily national'. Past strategies and those that are currently in vogue, and which are directed almost exclusively at exports, tend to drown local business capacities (which are usually not taken advantage of) and production for the internal market. To accomplish this, real salaries are contained and even reduced, giving rise to systems of increasingly predatory flexibilisation of labour relations to maintain or expand spurious international competitiveness for exports.

Here it is important to mention the other avenue to improve competitiveness - which is also wrong and, to a large extent, complementary to the approach already mentioned - the plundering of the environment due to a detrimental scheme that places greater importance on short-term returns than on any other long-term considerations.

In all successful cases where primary goods are leveraged, it is crucial to adapt innovation and technology (cutting-edge, intermediate or traditional) to local conditions. But we need to be careful when we use this technique. We are well aware that this approach is not neutral. This is not meant as a conservative view of technological progress but instead reflects a concern about 
the direction that this process takes. Modern techniques are submitted to a process of capital valuation, which is toxic in many respects. Frequently, techniques are developed based on demand for capital accumulation. We should not forget that all techniques are endowed with a 'social form', which entails ways that we relate to each other and build our identities; just look at the society that 'produced' the automobile, and the type of energy it requires. So this is another point that we need to consider during transition processes.

If we return to our reflections, if we expand the export sector and its associated sectors at the same time as we increase salaries, this will drive a strong internal demand for mass consumption and simple goods that, over timewith the increase in the average income of the majority - can become more sophisticated. This will increase the returns on investment, which will be attracted to producing processed foods, clothing and durable goods to replace imports and stimulate consumption chains. Little by little, to supply the industries that produce consumer goods, new segments of equipment production, machinery and inputs will emerge to cover the demands and needs of productive infrastructure (investment chains). All of this has been reported in other cases.

The idea is to achieve-over time-maturity and adequate levels of complexity, which include diversification and higher levels of inter-intra-sectorial interaction to take advantage of greater economies of scale and develop dynamic comparative advantages. Export enclaves will acquire internal coherence; the dual economy will give way to an integrated national and local economy, whose dynamic development will be driven by internal momentum that will be endogenous to the development of its own productive forces and of the expansion of internal mass markets, which will be a counterweight to the plantation or monocrop economies, as well as those based on increasingly higher levels of oil exploitation and mining.

In line with this thinking, the expansion of domestic employment (and consequent wage rises) is not conceived as a later stage, to be achieved only after encouraging exports in the long run. The logic of the global market is not expected to generate virtuous chains spontaneously, particularly in terms of capitalist globalisation. Historic experiences show that with extensive and intensive exploitation of internal markets, little by little we will access the international market to develop authentic competitiveness for processed goods. But this is not the ultimate objective of these transitions, which is rather to build dignified and sustainable lives for all inhabitants.

In synthesis, the idea is to gradually transfer the surpluses of extractivism to strengthen non-extractivist productive activities that will ultimately replace extractivism. As other productive activities are strengthened, it will 
be possible to gradually suspend primary exports, which have caused grave socio-environmental problems.

\section{An Indispensable Strategic Conception of Autonomous Integration and 'International Insertion'}

The integrationist effort has focused mainly, up to this point in time, on trade relations, and has failed to drive complementarity and, to an even lesser extent, ensure regional sovereignty. Perhaps these limitations were due to the rent seeking practices that feed extractivism: another pathology to carefully consider. To achieve regional sovereignty, it is necessary to transform the integration between peoples in the region by creating a different type of integration than that which currently predominates.

In extractivist economies - with a high demand for capital and technology that work as enclaves (without integrating primary-export activities within the rest of the economy and society), the productive apparatus is subject to the vicissitudes of the global market. In particular, it is vulnerable to competition for other countries in similar positions, which seek to sustain their income without paying sufficient attention to adequately managing prices. Opportunities for regional integration, which are indispensable if domestic markets are to be expanded, disappear if neighbouring countries produce similar raw materials, compete with one another, and hold down their export prices instead of working together in regional blocks that expand their markets and increase the complexity of their productive apparatuses.

At all times, it is necessary to consider the international environment, which is charged with uncertainty and instability and is, quite often, contrary to the interests of countries that produce natural resources. This causes strategies that are simply directed at openness to lose their viability and runs the risk of creating only 'islets of modernity', which are, in other words, enclaves that are detached from the economy. And we cannot generate exports that leave the internal market without supply. It is thus necessary to overcome fashionable trends and to propose strategies that reflect an understanding of the fact that the internal market must be prioritised. This requires taking advantage of and developing internal potential based on local demand.

All of this implies a new way of operating internationally, which must run alongside the development of a new profile for internally sustainable productive specialisation. The idea is to define-in dynamic terms - the lines of production in each country (based on the logic of economic blocs), concentrating efforts on increasing competitiveness and productivity but from a systemic 
and sustainable perspective. It is necessary to increase levels of quality employment and income by making capital, rather than work, more flexible. Otherwise, the workforce risks being exploited. To accomplish this, it is necessary to apply structural policies to redistribute wealth and income.

This entails, as we should expect, a deliberated and planned process for productive reorganisation that begins with building consensus among the state, social sectors and different economic agents-public and private, but in particular among cooperatives, associations and communities in the framework of a long-term democratic process. ${ }^{9}$

In addition, we understand the need to make the internal market and the domestic productive apparatus more robust. This would be a prerequisite of sorts for establishing a productive system that is competitive with the system outside the country without overdetermining the national productive structure and patterns of consumption. Here it is necessary, among other things, to implement measures that encourage the transformation and dynamism of agriculture based on the demands of food sovereignty, and to recognise the need to adopt different patterns of consumption (in truth, it is necessary to dismantle consumerism, improve the distribution of income and wealth, provide large-scale jobs training, undertake education reform and absorb as well as generate technical progress).

We need an economy that generates surpluses for productive accumulation instead of feeding productivism, especially if the latter is sustained by imports. A society that is committed to this change will be in a position to strengthen all of its capacities and will be stronger in the face of adversity. And among the many environments in which transitions are urgent, we have the energy sector, which requires local, national, regional and even global action. ${ }^{10}$

\section{Initial Conclusions}

The initial goal is to raise questions about extractivism (Acosta, 2014) and economic growth within the debate. This is the only way that these issues will gain the necessary weight. There is still little willingness at the government level,

9 Perhaps under these conditions, with economic blocs of countries that generate complementary production, and where these blocs achieve self-sufficiency, particularly technological, it is possible that Ricardian comparative advantages will benefit all the participants in international trade, as opposed to the situation now, where international trade definitely creates winners and losers.

See, among other topics, the contribution of Acosta et al. (2013b). 
and even among citizens, to initiate this debate, given that both have assumed that the extractivist route, and moreover economic growth, are indisputable.

Many people continue to believe that we are nations of scroungers, sitting on a pot of gold, and that the solution lies solely and simply in the (efficient) extraction of natural resources. We need to understand that we truly have the capacity to free ourselves from the yoke of economic exploitation (local and external) and that, with our own work and without ceding abundant surpluses to central countries, we can overcome the extractivist model and perhaps even reconsider the conception of economic growth without assuming that it is some kind of indisputable religion.

It must be clear that the extractivist economy (meaning mainly primaryexport) perpetuates our underdevelopment and makes it impossible for us to build buen vivir, or sumak kawsay. We can experience periods of economic boom, which are driven by high prices in the global market, but sooner or later, new crises will appear on the scene. And during these periods of scarcity, the curses generated by extractivism will worsen.

It is thus vital to overcome extractivist dependence. But to do this, we will need to develop and execute precise strategies that are flexible enough to address the challenges that this transition will imply.

In synthesis, to provide a structural solution to inequity and inequality, we must change the modality of accumulation, which implies giving way to visions and actions that move towards post-extractivism. But this, although important, is not the only consideration. We need changes based on strategic horizons other than capitalism. If we remain within capitalism, economic inequality and environmental degradation will never be overcome.

Hence, the reflections made under previous points should be aligned with referential elements of buen vivir, meaning 'this is the most attractive alternative to capitalistic modernity' (Giraldo, 2014). This conception of life, where relationality plays a preponderant role, will require an incessant and complex flow of interactions and exchanges. Giving and receiving, through a neverending process of reciprocities, complementarities and solidarities, constitutes the basis for buen vivir. This means we must assume an ethical stance that should govern human lives: take care of yourself and other living beings. In this world of harmonies, life takes precedence over any other consideration. We would say, in terms of political confrontation, that buen vivir is concerned with reproducing life and not capital.

The concepts of buen vivir need to be understood from different perspectives. It is important to avoid homogenising conceptions, which restrict the visions and understanding of alternative approaches. Despite this, at the core of the debate is the holistic view of life in a community and of the Pacha Mama 
(Mother Earth), where each has a relation to and complementarity with the other. These two elements-community and nature-set the bases upon which to build the proposals of buen vivir. But something else is needed. The spiritual world of the indigenous cultures is essential to buen vivir - their sumak kawsay.

Now that this point has been made, to learn lessons that allow us to build the economy of buen vivir, we must recognise the limitations of the conventional economy by using, as a key reference, the foundational elements of the indigenous world view. In particular, we need to value and understand what represents social justice and ecological justices, which are intimately interrelated given that one does not exist without the other.

The challenge that we have proposed - to rethink the economy from the perspective of buen vivir-will not be met overnight. And there is no recipe to set us on the path. We need to give way to transitions based on the thousands and thousands of alternative practices that exist all over the planet; practices that are guided by visions that propose a life of harmony among human beings and between human beings and nature. This requires, as discussed above, moving towards a new civilisation: moving, at the very least, from anthropocentrism to biocentrism and leaving behind utilitarianism. This new civilisation will not arise spontaneously, and will instead be the result of patient and decided construction and reconstruction, which will begin with dismantling various fetishes (such as the fetish for money and earnings) and trigger radical changes, whether based on existing experiences or on other options in the search for new worlds.

This is the crux of the matter. We have alternative values, experiences and practices such as buen vivir or the sumak kawsay or suma qamaña of the indigenous communities of the Andes or Amazon. ${ }^{11}$ In addition, in the visions of our America, there are many other approximations of thoughts that are in some way linked to the search for a harmonious life through inclusive philosophical visions across continents. Buen vivir, as a way of life, with different names and varieties, is known and practiced in different regions of Madre Tier$r a$, including as part of ubuntu in Africa or swaraj in India. And there are many, many more experiences across the planet that are immersed in a marvellous and complex process of re-enchanting the world. ${ }^{2}$

11 See Gudynas (2014), Estermann (2014), Omar Felipe Giraldo (2014), Atawallpa Oviedo (2011), and Acosta (2013), among others.

12 As proposed by Morris Berman (1987), whose contribution will serve to rectify the dominant epistemology and build a new paradigm that understands, in practice, that human beings are an integral part of the life of Mother Earth and of the Universe. 
Buen vivir, without forgetting and even less without manipulating its ancestral origins, can serve as a platform to discuss, agree upon and apply answers to the devastating effects of climate change across the planet and growing instances of exclusion and social violence in the world. We can even propose a change in paradigm amid the crisis that central countries are experiencing. In this regard, building buen vivir, as part of profoundly democratic processes, can be useful to finding global answers to the challenges that humanity faces.

Buen vivir, which emerges from utopic visions, is present in different manners in the reality of the still existing capitalist system and feeds on the imperative need to promote harmonious living among human beings and between human beings and nature; this is a life that puts the self-sufficiency and self-management of human beings who live in communities at the core of its existence. Thus, it will be difficult to imagine building buen vivir solely through government policy that is driven by forces up above, given that it requires another kind of regional integration, where the community and not the state is the fundamental determinant.

This implies keeping in mind a change in era. It is necessary to move beyond postmodernity, which has generated discontent. We cannot continue to promote a model of devastating development, which contemplates unsustainable economic growth in its paradigm of modernity. Rather, we must overcome the idea of progress understood as the permanent accumulation of material goods.

To begin, we must reunite with the 'utopic dimension', as proposed by Alberto Flores Galindo. This implies strengthening the basic values of democracyliberty, equality, solidarity and equities — by including diverse approximations and conceptual valuations of life in the community. In these new forms of life, and based on real tolerance, we will need to respect, for example, diverse sexual options and forms of organisation of families and communities.

Buen vivir - meaning the philosophy of life-opens the door to the building of an emancipating project. The fact that we do not have a predetermined path is not an issue. On the contrary, it frees us of dogmatic visions but demands more clarity in terms of our destination, and assuming the transition towards another civilisation as part of buen vivir.

In summary, with the diverse positive co-existences and multiple anti-system —or outside of the system — responses that exist in different corners of the world, it is up to us to build a world that can contain other worlds, in which there are no victims of isolation or exploitation, and where all human beings live with dignity and in harmony with nature. 


\section{References}

Acosta, A. (2014) 'Post-crecimiento y post-extractivismo: Dos caras de la misma transformación cultural', in G. Endara (ed.) Post-crecimiento y Buen Vivir. Propuestas globales para la construcción de sociedades equitativas y sustentables (Quito: FESILDIS), http://www.rebelion.org/noticia.php?id=196977 (accessed on 18 September 2016).

Acosta, A. (2013) El Buen Vivir. Sumak Kawsay, una oportunidad para imaginar otros mundos (Barcelona: Icaria).

Acosta, A. (2009) La maldición de la abundancia (Quito: CEP, SwissAid and Abya-Yala). Acosta, A. and J. Cajas (2015) 'Instituciones transformadoras para la economía global. Pensando caminos para dejar atrás el capitalismo', in M. Lang, B. Cevallos and C. López (eds.) La osadía de lo nuevo. Alternativas de política económica, Grupo Permanente de Trabajo sobre Alternativas de Desarrollo de la Fundación Rosa Luxemburg (Quito: Fundación Rosa Luxemburg/Abya-Yala).

Acosta, A., E. Martínez and W. Sacher (2013b) 'Salir del extractivismo: una condición para el Sumak Kawsay. Propuestas sobre petróleo, minería y energía en el Ecuador', in M. Lang et al. (eds.) Alternativas al capitalismo/ colonialismo del siglo XXI, Grupo Permanente de Trabajo sobre Alternativas de Desarrollo de la Fundación Rosa Luxemburg (Quito: Fundación Rosa Luxemburg y Abya Yala).

Amann, S., S. Böll, M. Dettmer, M. Hesse and J. Tietz (2014) 'Bitte unten bleiben!' Der Spiegel, 5 May, http://www.spiegel.de/spiegel/print/d-126830901.html (accessed on 23 March 2017).

Berman, M. (1987) El Reencantamiento del Mundo (Santiago de Chile: Cuatro Vientos).

Bhagwati, J. (1958) 'Immiserizing growth: A geometrical note', Review of Economic Studies, 25(3), pp. 201-205, http://www.jstor.org/stable/2295990.

Ceceña, A.E. (2008) Dominar la naturaleza o vivir bien: disyuntiva sistémica (Mexico: Observatorio Latinoamericano de Geopolitica, Universidad Nacional Autónoma de México), http://www.geopolitica.ws/media/uploads/vivirbienodominarlanaturaleza.pdf (accessed on 21 November 2016).

Durand, F. (2006) La mano invisible en el Estado. Efectos del neoliberalismo en el empresariado y la política (Lima: Desco/FES).

Echeverría, B. (2010) Modernidad y blanquitud (México: Editorial ERA).

Estermann, J. (2014) 'Ecosofía andina-Un paradigma alternativo de convivencia cósmica y de vida plena' in A. Oviedo Freire (ed.) Bifurcación del Buen Vivir y el sumak kawsay (Quito: Ediciones SUMAK).

Giraldo, O.F. (2014) Utopias en la era de la supervivencia-Una interpretación del Buen Vivir (México: Editorial ITACA).

Gudynas, E. (2014) 'Buen Vivir: sobre secuestros, domesticaciones, rescates y alternativas', in A. Oviedo Freire (ed.) Bifurcación del Buen Vivir y el sumak kawsay (Quito: Ediciones SUMAK). 
Honty, G. and E. Gudynas (2014) Cambio climático y transiciones al buen vivir. Alternativas al desarrollo para un clima seguro (Lima: CLAES and RedGE de Perú).

Keynes, J.M. (2003) [1933] 'Autosuficiencia Nacional', Ecuador Debate $\mathrm{N}^{\circ}$ 6o, December (Quito: CAAP), http://repositorio.flacsoandes.edu.ec/bitstream/10469/5288/1/ RFLACSO-ED6o-16-Maynard.pdf (accessed on 23 March 2017). [Original text: 'National Self-Sufficiency', The Yale Review, 22(4), pp. 755-769].

Myrdal, G. (1957) Economic Theory and Under-developed Regions (London: Duckworth).

Oviedo Freire, A. (2011) Qué es el sumakawsay. Más allá del socialismo y capitalismo (Quito: Sumak editores).

Oxfam (2016) Una economia al servicio del $1 \%$. Acabar con los privilegios y la concentración de poder para frenar la desigualdad extrema, https://www.oxfam.org/sites/ www.oxfam.org/files/file_attachments/bp210-economy-one-percent-tax-havens -180116-es_o.pdf (accessed on 9 November 2016).

Pinto, A. (1970) 'Naturaleza e implicaciones de la "heterogeneidad estructural" de la América Latina', El Trimestre Económico, 37(145), pp. 83-100.

Schuldt, J. (1994) La enfermedad holandesa y otros virus de la economía peruana (Lima: Universidad del Pacífico).

Schuldt, J. and A. Acosta (200o) 'Algunos elementos para repensar el desarrollo. Una lectura para pequeños países', in A. Acosta (ed.) El desarrollo en la Globalización (Caracas: Editorial Nueva Sociedad).

Stiglitz, J. (2006) Cómo hacer que funcione la globalización (Madrid: Taurus). 